\title{
Morpho-physiological Qualities and Evaluation of Germinative Behavior of Hyptis suaveolens Poit (Big balm) Seeds
}

\author{
Kéassemon Hervé Cédessia Kone ${ }^{1 *}$, Dramane Soro ${ }^{1,2}$, Blé Alexis Tardy Kouassi ${ }^{1}$, \\ Oulé Démétché Epiphanie Dion ${ }^{1}$ and Lacina Fanleguecoulibaly ${ }^{2}$
}

\author{
${ }^{1}$ Université Péléfero Gon Coulibaly, UFR des Sciences Biologiques, Département de Biologie \\ Végétale, BP 1328 Korhogo \\ ${ }^{2}$ Centre Suisse de Recherches Scientifiques en Côte d'Ivoire \\ *Corresponding author
}

\section{A B S T R A C T}

Keywords

Hyptis suaveolens, weed, germination, biological control, Ivory Coast

\section{Article Info}

\section{Accepted:}

15 September 2020 Available Online: 10 October 2020
Hyptis suaveolens (L.) Point. (Lamiaceae) is a threat of biodiversity, environment and especially crops and pastures. This species has high propagation capacity in the environment. This study was initiated to contribute to the biological control of Hyptis suaveolens. To achieve this objective, morphological and physiological characteristics of seeds were realized. Mean length of $3.55 \pm 0.18 \mathrm{~mm}$, mean width of $2.20 \pm 0.13 \mathrm{~mm}$ and mean thickness of $0.84 \pm 0.08 \mathrm{~mm}$ were obtained. A purity rate of $94.4 \% \pm 2.96$ and mean number of 4850 seeds per gram were also obtained at morphological study. At physiological level, germination rate of $64.25 \%$ and percent water content of $10.2 \pm 1.79 \%$ were obtained. Physical scarification reduced germination to $16 \%$ at micropylar level (CMI) and $31 \%$ at opposite side of micropyl (COM). Chemical scarification had virtually no germination rate. After three (3) months of storage, germination rate of $63.25 \%$ in refrigerated and $23.00 \%$ in ambient condition were observed. Change light and darkness was more favorable for better seed germination with $80 \%$ germination rate compared to $74.25 \%$ in light and $53.75 \%$ in darkness. These results could help effectively to combat this invasive plant.

\section{Introduction}

Hyptis suaveolens (L.) Poit. Lamiaceae is native in American tropic. It has spread rapidly on all continents with acuity in Mediterranean basin of Central Asia and in Sub-Saharan Africa (Thiombiano et al., 2009). It is widely used in traditional medicine for its pharmacological and bacteriological properties. Hyptis suaveolens is sudorific, antispasmodic, galactogenic, insect repellent and insecticide plant (Ngom et al., 2012).

The leaves are used as tea, infused, decocted and poultice forms. The decocted of these leaves has used to treat asthma, jaundice and hyperthermia. The leaves are consumed against head pain, euphoric, bechic, stimulating and thinning of bronchial secretions as tea form (Bissangou and Ouamba, 1997). Despite all these used, Hyptis 
suaveolensis an invasive plant. It infests cities, villages, fields, wasteland and roads (Madjidou et al., 2010; Aboh, 2008). Furthermore, its presence also compromises agro-pastoral activities because it is not appetized by animals (Thiombiano et al., 2009; Thiombiano, 2008).

Hyptis suaveolens has a great capacity of propagation and also has strong capacity of regeneration in new biotopes. Therophyte plant, many feet species are able to get through bad season and seems to progressively evolve to Chamephyte stage (Thiombiano et al., 2009).

Many studies of this plant have concerned therapeutic aspect. Few of them have focused on biological control. This study aims to focus on morphological and physiological characteristics of seeds of Hyptis suaveolens.

\section{Materials and Methods}

\section{Study site}

This work was carried out in Poro region in Korhogo department in Northen Côte d'Ivoire (Figure 1). It is limited in Mali Republic in North, at Bounkani in South, at Tchologo and Hambol in East and in West by Bagoué area (CGK, 2007).

\section{Seeds harvest}

Seeds harvest was done by mowing and bearing mature fruits. Protective envelopes and stems was separated with seeds by threshing of harvested.

\section{Morphological and physiology description of seeds}

The morphological study consisted to realize physical parameters including length, width, thickness, specific purity of seeds of $H$. suaveolens and number of seeds per gram. The physiological parameters study has consisted to evaluate water content, germination time, germination rate, means germination time and germination speed.

\section{Seeds specific purity}

Seeds gram (1g) was taken with four repetitions. They were selected at random from entire seed using precision balance (Kameswara et al., 2006). Plant debris and sand were removed using fine forceps, than seeds were weighed. Purity percent was calculated according to following formula.

$$
\text { Percent purity }(\%)=\frac{\text { Pure seed weight }(g)}{\text { Total sample weight }(g)}
$$

\section{Means seed size and number}

Length, width and thickness means of seeds measurements, were carried out using caliper. Seeds mean number per gram has been calculated using the formula below.

Seeds mean number $=\frac{\sum \text { pure seeds number of lot }}{\text { Total number of lots }}$

Germination capacity of Hyptis suaveolens seeds

Germination capacity percent (CG) was calculated from number of seeds germinated daily according to the formula below.

$$
\% \mathbf{C G}=\left(\sum \mathbf{n}_{\mathrm{i}} / \mathbf{N}\right) \times \mathbf{1 0 0}
$$

$n i$ is germinated seeds number a day, $N$ is total seeds number.

The germination time corresponds to necessary time (in days) to observe first germinated seed, and germination speed is time necessary to obtain $50 \%$ of germination capacity (Côme, 1982). 


\section{Seed germination conditions}

Different parameters influencing germination of $H$. suaveolens seeds have been studied. These are physical and chemical scarification and light impact on germination capacity of seeds, the medium and shelf life of the seeds have been studied.

\section{Physical scarification impact on germination}

The lysis of seed coat by piercing with needle has allowed better penetration of water and oxygen. Mechanical materials were used. Three treatments were applied to 100 seeds with four replicates. In first group seeds were scarified at micropyl (CMI), second group has consisted of scarification on micropyl opposite side (COMI). The third treatment has concerned non-scarified seeds which has control group (TM). The seeds has sown in distilled water and then placed under germination conditions.

\section{Chemical scarification impact on germination}

Soaking time (TP5; TP15; TP30) and rate of acid dilution (DL0; DL50; DL100) have been combined. Each treatment is a combination of two factors. Untreated seeds have constituted control treatment (TM).

Four hundred (400) pure seeds were taken to form 4 samples of 100 seeds. These seeds were exposed to ambient temperature for five hours to remove moisture.

Seeds was placed in tray containing sulfuric acid dose. Seeds were washed in tap water for 5 to $10 \mathrm{mn}$ and spread in thin layer on sieve to wring them out. They were sown in germination tank. Distilled water was used for humidification.
Light, environment and storage time impact on germination

Seeds were placed in light, in dark, in light/dark alternating conditions. Treatments were applied to each group with four repetitions of 100 seeds. Batch was maintained in darkness; in light and dark alternate and in light, in distilled water for each treatment. The follow-up was carried out every day and germinated seeds were recorded and removed from test.

For environment and storage time impact, seeds were kept in refrigerated temperature (MR) at $7^{\circ} \mathrm{C}$ and in ambient medium (MA).After 1, 2 and 3 months of storage, seeds were extracted for viability tests.

\section{Data analysis and processing}

Excel spreadsheet was used for descriptive statistics and curves. XLSTAT 2014 and SATISTCA version 7.1 software were performed for statistical analyzes.

\section{Results and Discussion}

\section{Morphological parameters description}

Seeds of Hyptis suaveolens measurements have showed means length of $3.55 \pm 0.18$ $\mathrm{mm}$, means width of $2.20 \pm 0.13 \mathrm{~mm}$ and means thickness of $0.84 \pm 0.08$. For specific purity, seeds of Hyptis suaveolens are pure at $94.4 \% \pm 2.96 \%$. Means number of seeds per gramis4850 \pm 352 seeds (Table 1 ).

\section{Physiological parameters descriptions}

\section{Physical scarification effect on germination capacity}

In terms of physical scarification, Control seeds group (TM) recorded a strong growth in germination rate $(62 \%)$ on 6th day after 
sowing with germination speed of two days. Seeds scarified at micropylar level (COM) and on micropyl opposite side (CMI), have shown respectively germination rates of $16 \%$ and $31 \%$ as highest rates in the test. Statistical analyzes showed a significant difference between the three groups (Fig. 2).

\section{Chemical scarification effect}

Chemical scarification of seeds of Hyptis suaveolens showed considerable drop of germination rate with different doses of acid sulfuric used or time required for soaking. No-scarified seeds have shown highest germination rate $(34.75 \%)$, the other treatments did not have effect or had a very weak effect on seeds germination. The statistical tests showed that there is a significant difference between acid treatments group and the control group. In general, longer of duration of soaking has provoked less of seeds germinated. Tests with same letters in the columns are not statistically different at 5\% level (Fig. 3).

\section{Influence of light on seeds germination}

Seeds are germinated in all light conditions in this study. The highest germination rates were recorded at 8th day after sowing for the three tests group. It was $53.75 \%$ in darkness condition, $74.25 \%$ at light and $80 \%$ light / dark alternation. Statistical analyzes performed have shown that seed germination varies with light condition at $\mathrm{P}(0.01)<$ 0.05(Fig. 4).
Environmental and storage duration impact on seeds germination

Germination rate of Hyptis suaveolens seeds was studied according to environment and duration of storage. After 1 month of storage, means germination rate of $62.75 \%$ in the cold $\left(7^{\circ} \mathrm{C}\right)$ and $65.66 \%$ in an ambient environment were obtained. Statistical analysis showed that after one month of storage, germination was same in both groups.

At two (2) months of storage, germination of seeds stored in cold $\left(7^{\circ} \mathrm{C}\right)$ and in the ambient environment was different. The germination rate was $61 \%$ in a refrigerated temperature against $43.25 \%$ in an ambient condition.

Three (3) months of storage after, $63.25 \%$ and $23.00 \%$ germination rates were obtained respectively in refrigerated environment and in ambient environment. Analyzes of variance revealed that conservation in refrigerated environment is more effective than conservation in an ambient condition (Table2).

Hyptis suaveolens seeds measurements has showed means thickness of $0.84 \pm 0.08 \mathrm{~mm}$, means width of $2.20 \pm 0.13 \mathrm{~mm}$ and means length of $3.55 \pm 0.18 \mathrm{~mm}$. This result is different from those of Aboh (2008) in terms of length in a similar study in Benin. For this author, means length was $2 \mathrm{~mm}$, that could be due to the difference in local or geographic conditions.

Table.1 Morpnological parameters measured

\begin{tabular}{|c|c|}
\hline Morphological parameters & Means values \\
\hline Length $(\mathbf{m m})$ & $3.56 \pm 0.19$ \\
\hline Width $(\mathbf{m m})$ & $2.20 \pm 0.13$ \\
\hline Thickness $(\mathbf{m m})$ & $0.84 \pm 0.08$ \\
\hline Specific purity (\%) & $94.40 \pm 2.96$ \\
\hline Number of seeds & $4850 \pm 352$ \\
\hline
\end{tabular}


Table.2 Means germination rate of Hyptis suaveolens seeds with storage time

\begin{tabular}{|c|c|c|c|c|}
\hline Storage time & $\begin{array}{c}\text { Temperature } \\
\text { Conditions }\end{array}$ & Means rate & $\mathbf{F}$ & $\operatorname{Pr}>\mathbf{F}$ \\
\hline \multirow[t]{2}{*}{1 month } & Refrigerated condition & $62.75 a$ & \multirow[t]{2}{*}{0.41} & \multirow[t]{2}{*}{0.50} \\
\hline & Ambient condition & $65.66 \mathrm{a}$ & & \\
\hline \multirow[t]{2}{*}{2 month } & Refrigerated condition & $61.05 \mathrm{a}$ & \multirow[t]{2}{*}{16.37} & \multirow[t]{2}{*}{$0.01 *$} \\
\hline & Ambient condition & $45.00 \mathrm{~b}$ & & \\
\hline \multirow[t]{2}{*}{3 month } & Refrigerated condition & $63.25 \mathrm{a}$ & \multirow[t]{2}{*}{17.30} & \multirow[t]{2}{*}{$0.01 *$} \\
\hline & Ambient condition & $23.00 \mathrm{~b}$ & & \\
\hline
\end{tabular}

Fig.1 Map of the Poro region (Côte d'Ivoire)

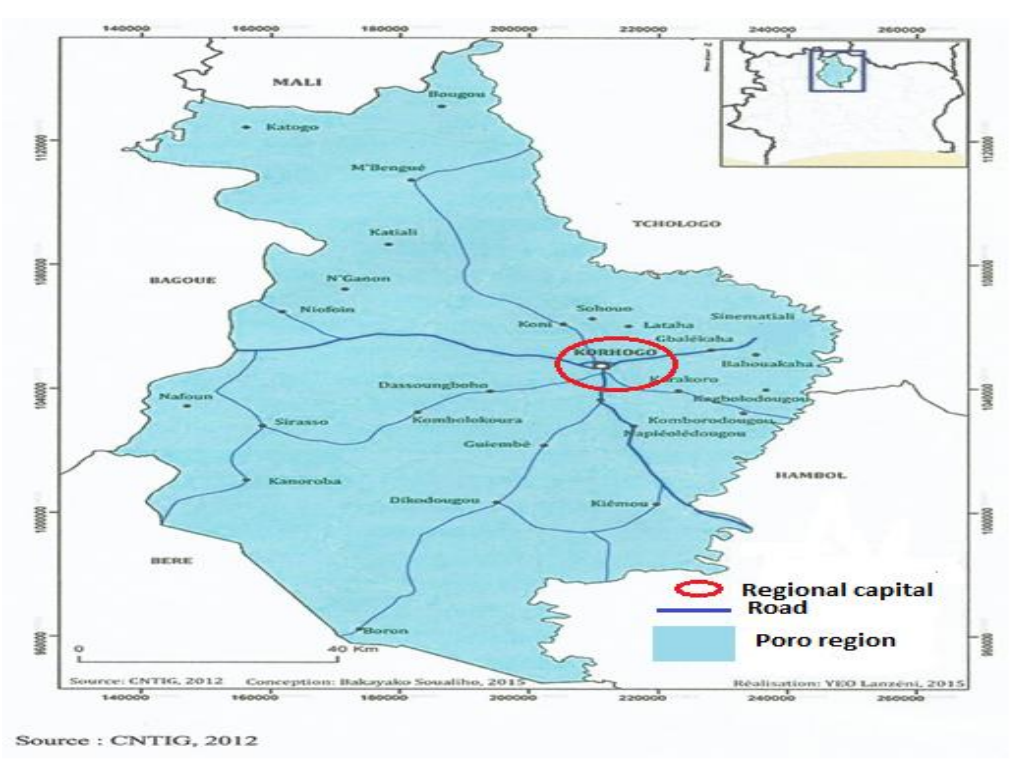

Fig.2 Effect of physical scarification on Hyptis suaveolens seeds germination capacity

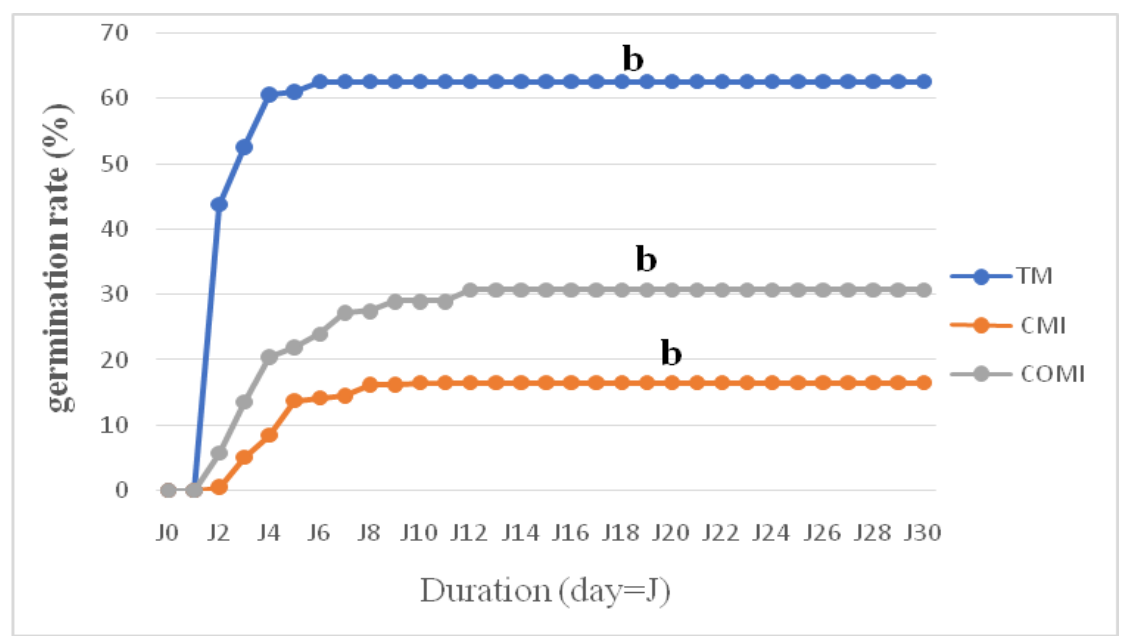


Fig.3 Evolution of germination rate of Hyptis suaveolens seeds with soaking time and acid dilution

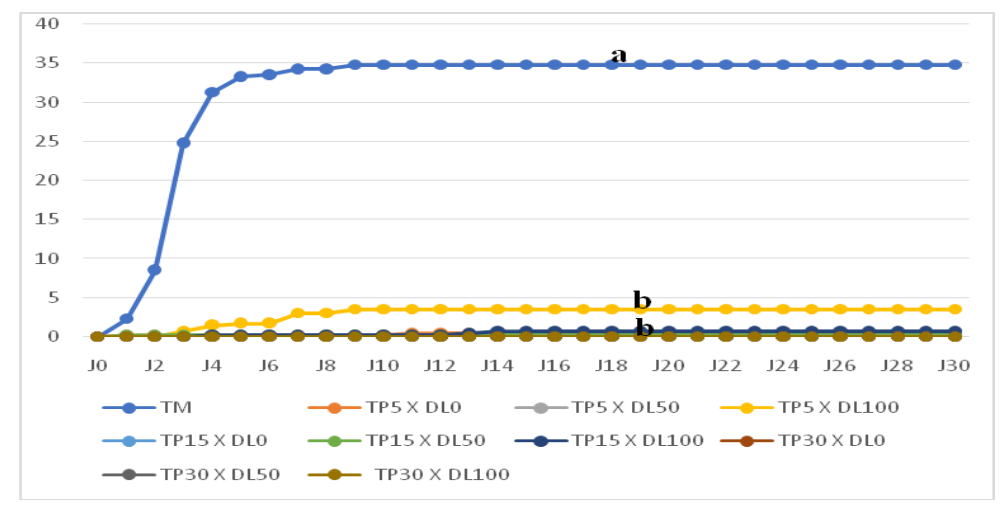

Fig.4 Evolution of germinative capacity of Hyptis suaveolens seeds with light conditions

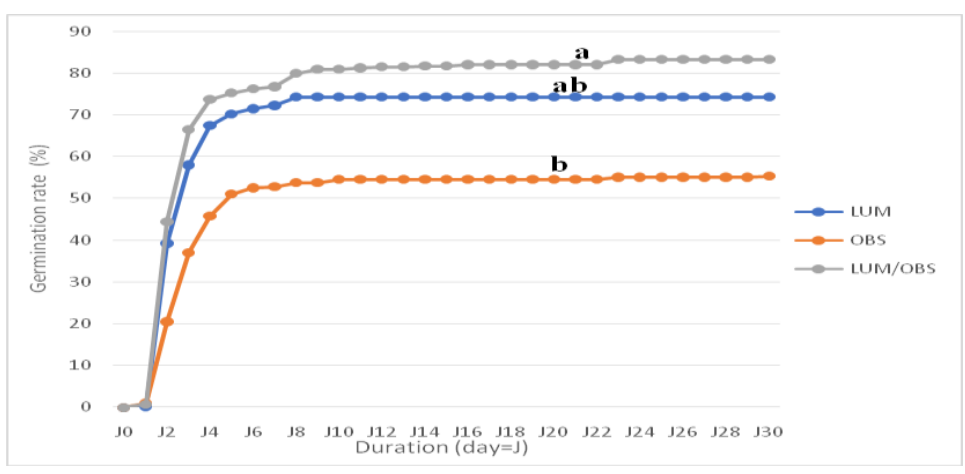

The purity rate of $94.4 \% \pm 2.96 \%$ and means number of seeds of $4850 \pm 352$ seeds per gram were obtained. Thiombiano (2008) obtained similar result with 6.5 grams of seeds per foot of Hyptis suaveolens. For Aboh (2008) square meter $\left(\mathrm{m}^{2}\right)$ of soil occupied by this plant could produce more than 5000 seeds. All those studies revealed that Hyptis suaveolens has a high capacity to produce seed.

The scarified seeds recorded a low germination rate. This result could be justified because physical scarification reduces the germination capacity of seeds. Micropylar region should be avoided because it is the most sensitive part. Embryo is located on it (Kameswara et al., 2006).
Sulfuric acid treatmentrevealled low germination rate of Hyptis suaveolens seeds. That could be explained because sulfuric acid treatment has inhibited germination of seeds. These observations would lead that there is no dormancy in Hyptis suaveolens seeds Caesar (2008).

Studies of Hyptis suaveolens seeds viability have shown that refrigerated temperature is better at seeds conservation than ambient temperature. This result is similar to those of Cole (1979) who obtained same result with Hyptis suaveolens and contrary result with Panicum laxum (Poaceaae). This could be explained because Hyptis suaveolens (Lamiaceae) and Panicum laxum (Poaceaae) are from different botanical families. 


\section{Conclusion and perspectives}

This study aim to determine morphological and physiological characteristics of Hyptis suaveolens seeds. At morphological level, means length of $3.55 \pm 0.18 \mathrm{~mm}$, means width of $2.20 \pm 0.13 \mathrm{~mm}$ and means thickness of $0.84 \pm 0.08 \mathrm{~mm}$ have been obtained. A purity rate of $94.4 \% \pm 2.96 \%$ and means number of $4850 \pm 352$ seeds per gram have been obtained. Physiologically, means germination rate of $64.25 \%$ and means water content of $10.2 \pm 1.79 \%$ have been obtained. The two types of scarification carried out, inhibited germination of seeds. Physical scarification germination to $16 \%$ at micropylar level (MIC) and to $31 \%$ at opposite side of micropyl $(\mathrm{COM})$. Chemical scarification recorded almost zero germination rate. At three (3) months of storage, germination rate of $63.25 \%$ in refrigerated condition and $23.00 \%$ in ambient condition have been observed. An alternation of light and dark is more favorable for better germination of seeds with $80 \%$ germination rate against $74.25 \%$ in light and $53.75 \%$ in dark. Morphological and physiological seeds parameters studied of Hyptis suaveolens could be used to develop or improve effective and sustainable method of control of this plant.

\section{References}

Aboh B. A. (2008). Phytosociologie, écologie, potentialités et aménagement des pâturages naturels envahis par Chromolaena odorata et Hyptis suaveolens en Zone Soudano guinéenne (Bénin). Thèse de Doctorat, Université d'Abomey- Calavi 'UAC). Bénin, 219p.

Aisa. (1991). Le développement agro- pastoral et agro-industriel du Nord de la Côte d'Ivoire : cas des départements de Korhogo, Boundiali, Ferkéssédougou. AISA, Abidjan, 133p.

Bamba K. (2014). Mémoire de fin de cycle, Evaluation de l'itinéraire technique de la culture de l'oignon dans la commune de
Korhogo- Côte d'Ivoire, pp 11-15.

Barralis G. (1984). Adventices des cultures 50 à 500 millions de semences/ ha. Cultivar, spécial désherbage, 178 : pp 16-19.

Beaudou E et Sayol R. (1980). Etude pédologique de la région de Boundiali- Korhogo (Côte d'Ivoire). ORSTOM. Paris, France, 13p.

Bissangou M. F., Ouamba J. M. (1997). Valorisation chimique de quelques espèces aromatiques et médécinales du Congo: Ageratum conyzoides L., Chromolaena King et Robinson, Hyptis suaveolens Poit et Lippia multiflora Moldenke. Rev Pharm, Med Trad9, pp. 70-84.

César B. (2008). Hyptis suaveolens (L.) Poit. Dans les systèmes agropastoraux de la communauté rurale de Mlomp: étude de quelques aspects de la biologie, de l'écologie et proposition de méthodes de contrôle. Mémoire pour l'obtention du Diplôme d'Etudes Approfondies (DEA). Université Cheik Anta Diop de Dakar. Dakar, 107p.

CGK. (2007). Plan stratégique de développement du département de Korhogo. Tome 1 : Diagnostic stratégique, $9 \mathrm{p}$.

Cole A. N. H. (1977). Effet of ligh, temperature and flooding on seed germination of the neotropical Panicum laxum. Biotropium,9(3), 191-194.

Comboigo S. M. (2014). Inventaire des mauvaises herbes dans la culture cotonnièredansle terroir de Kounandia. Rapport de stage de fin de premier cycle. Université polytechnique de Bobo Dioulasso (UPB). Bobo Dioulasso, 16p.

Djimadum. (1993). Adventices des cultures dans la région de Bondoukouy, étude de la flore, de l'écologie et de/ la nuisibilité. Mémoire de fin d'étude d'ingénieur du développement Rural en Agronomie, 122p.

Elisabeth L. G. (1979). Etude expérimentale des propriétés germinatives de quelques semences sahéliennes, 39p.

Johan. S. (2002). Analyse technique et économique des systèmes de production agricole au Nord de la Côte d'Ivoire. Thèse de Doctorat, No 530 à la faculté des sciences biologiques, Université de Cocody (Abidjan, Côte d'Ivoire), 9 et 15p.

Kameswara N. R., Jean H., Ehsan M. D., Kkoli 
G., David N., Michael L. (2006). Manuel de manipulation des semences dans les banques de gènes. Manuels pour les banques de gènes. No, 8. Biodiversity international, Rome, Italie, 165p.

Karkour L. (2012).La dynamique des mauvaises herbes sous l'eefet des pratiques culturales, dans la zone des plaines intérieures. Mémoire d'ingéniorat en production végétale et agriculture de conservation, $158 \mathrm{P}$.

Koné K. H. C. (2017). Lutte contre les mauvaises herbes. 40p.

Madjidou O., Boya A. A., Sévérin B., Marcel H., Brice S. (2010). Int. J. Biol. Chem. Sci, 4(4), 1262- 1277.

ORSTOM. (1966).Note sur la physiographie générale du bassin versant de WaraniénéDoka et des bassins versants environnants, $2 p$.

Perraud A. (1971). Les sols. In : Le milieu naturel de la Côte d'Ivoire. ORSTOM, Paris (France), 1-70.

Saliou N., Fatou D. F., Moussoukhoye D., Jean M. K., Abdoulaye SC. (2012). Composition chimique et propriétés physico- chimique des huiles essentielles d'Ocimum basilicum et d'Hyptis suaveolens (L) Poit. Récoltés dans la région de Dakar au Sénégal. Bulletin de la Société Royale des Sciences de Liège, vol. 80, pp166- 175.

Soro G., Ouattara A. (2018). Mémoire de fin de cycle, la jachère à légumineuse dans la région de Korhogo (Nord $\mathrm{CI}$ ), production litière et évolution de la flore adventice sous les espèces introduites et régénération d'Acacia auriculiformis (Mimosaceae) à partir des souches, 25p.

Terry P.J. (1983). Some common Crop West Africa and their ControlUSAID, 132p.

Thimobiano N., Ouédrago R. L., Belem M., Guinho S. (2009). Dynamique de l'évolution et impact d'une plante envahissante au Burkina Faso: Hyptis suaveolens (L.) Poit. Serie sciences, Tome XVIII,pp 97-115.

Thiombiano D. N. E. (2008). Etude de trois espèces à tangence prolifique et envahissante dans la province de Boulkiendé: essai de valorisation (Burkina Faso). Mémoire d'Ingénieur des Eaux et
Forêts IDR/ UPB. Bobo Dioulasso, 108p.

Aboh B. A. (2008). Phytosociologie, écologie, potentialités et aménagement des pâturages naturels envahis par Chromolaena odorata et Hyptis suaveolens en Zone Soudano guinéenne (Bénin). Thèse de Doctorat, Université d'Abomey- Calavi 'UAC). Bénin, 219p.

Aisa. (1991). Le développement agro- pastoral et agro-industriel du Nord de la Côte d'Ivoire : cas des départements de Korhogo, Boundiali, Ferkéssédougou. AISA, Abidjan, 133p.

Bamba K. (2014). Mémoire de fin de cycle, Evaluation de l'itinéraire technique de la culture de l'oignon dans la commune de Korhogo- Côte d'Ivoire, pp 11-15.

Barralis G. (1984). Adventices des cultures 50 à 500 millions de semences/ ha. Cultivar, spécial désherbage, 178 : pp 16-19.

Beaudou E et Sayol R. (1980). Etude pédologique de la région de Boundiali- Korhogo (Côte d'Ivoire). ORSTOM. Paris, France, 13p.

Bissangou M. F., Ouamba J. M. (1997). Valorisation chimique de quelques espèces aromatiques et médécinales du Congo: Ageratum conyzoides L., Chromolaena King et Robinson, Hyptis suaveolens Poit et Lippia multiflora Moldenke. Rev Pharm, Med Trad, pp. 70-84.

César B. (2008). Hyptis suaveolens (L.) Poit. Dans les systèmes agropastoraux de la communauté rurale de Mlomp: étude de quelques aspects de la biologie, de l'écologie et proposition de méthodes de contrôle. Mémoire pour l'obtention du Diplôme d'Etudes Approfondies (DEA). Université Cheik Anta Diop de Dakar. Dakar, 107p.

CGK. (2007). Plan stratégique de développement du département de Korhogo. Tome 1: Diagnostic stratégique, $9 \mathrm{p}$.

Cole A. N. H. (1977). Effet of ligh, temperature and flooding on seed germination of the neotropical Panicum laxum. Biotropium, 9(3), 191-194.

Comboigo S. M. (2014). Inventaire des mauvaises herbes dans la culture cotonnièredansle terroir de Kounandia. Rapport de stage de fin de premier cycle. Université polytechnique de Bobo Dioulasso (UPB). 
Bobo Dioulasso, 16p.

Djimadum. (1993). Adventices des cultures dans la région de Bondoukouy, étude de la flore, de l'écologie et de/ la nuisibilité. Mémoire de fin d'étude d'ingénieur du développement Rural en Agronomie, 122p.

Elisabeth L. G. (1979). Etude expérimentale des propriétés germinatives de quelques semences sahéliennes, 39p.

Johan. S. (2002). Analyse technique et économique des systèmes de production agricole au Nord de la Côte d'Ivoire. Thèse de Doctorat, No 530 à la faculté des sciences biologiques, Université de Cocody (Abidjan, Côte d'Ivoire), 9 et 15p.

Kameswara N. R., Jean H.,Ehsan M. D., Kkoli G., David N., Michael L. (2006). Manuel de manipulation des semences dans les banques de gènes. Manuels pour les banques de gènes. No, 8. Biodiversity international, Rome, Italie, 165p.

Karkour L. (2012).La dynamique des mauvaises herbes sous l'eefet des pratiques culturales, dans la zone des plaines intérieures. Mémoire d'ingéniorat en production végétale et agriculture de conservation, $158 \mathrm{P}$.

Koné K. H. C. (2017). Lutte contre les mauvaises herbes. 40p.

Madjidou O., Boya A. A., Sévérin B., Marcel H., Brice S. (2010). Int. J. Biol. Chem. Sci, 4(4), 1262- 1277.

ORSTOM. (1966). Note sur la physiographie générale du bassin versant de WaraniénéDoka et des bassins versants environnants,
$2 \mathrm{p}$.

Perraud A. (1971). Les sols. In : Le milieu naturel de la Côte d'Ivoire. ORSTOM, Paris (France), 1-70.

Saliou N., Fatou D. F., Moussoukhoye D., Jean M. K., Abdoulaye S. C. (2012). Composition chimique et propriétés physico-chimique des huiles essentielles d'Ocimum basilicum et d'Hyptis suaveolens (L) Poit. Récoltés dans la région de Dakar au Sénégal. Bulletin de la Société Royale des Sciences de Liège, vol. 80, pp166- 175.

Soro G., Ouattara A. (2018). Mémoire de fin de cycle, la jachère à légumineuse dans la région de Korhogo (Nord $\mathrm{CI}$ ), production litière et évolution de la flore adventice sous les espèces introduites et régénération d'Acacia auriculiformis (Mimosaceae) à partir des souches, 25p.

Terry P.J. (1983). Some common Crop West Africa and their Control USAID, 132p.

Thimobiano N., Ouédrago R. L., Belem M., Guinho S. (2009). Dynamique de l'évolution et impact d'une plante envahissante au Burkina Faso: Hyptis suaveolens (L.) Poit. Serie sciences, Tome XVIII,pp 97-115.

Thiombiano D. N. E. (2008). Etude de trois espèces à tangence prolifique et envahissante dans la province de Boulkiendé : essai de valorisation (Burkina Faso). Mémoire d'Ingénieur des Eaux et Forêts IDR/ UPB. Bobo Dioulasso, 108p.

\section{How to cite this article:}

Kéassemon Hervé Cédessia Kone, Dramane Soro, Blé Alexis Tardy Kouassi, Oulé Démétché Epiphanie Dion and Lacina Fanleguecoulibaly. 2020. Morpho-physiological Qualities and Evaluation of Germinative Behavior of Hyptis suaveolens Poit (Big balm) Seeds. Int.J.Curr.Microbiol.App.Sci. 9(10): 1764-1772. doi: https://doi.org/10.20546/ijcmas.2020.910.214 